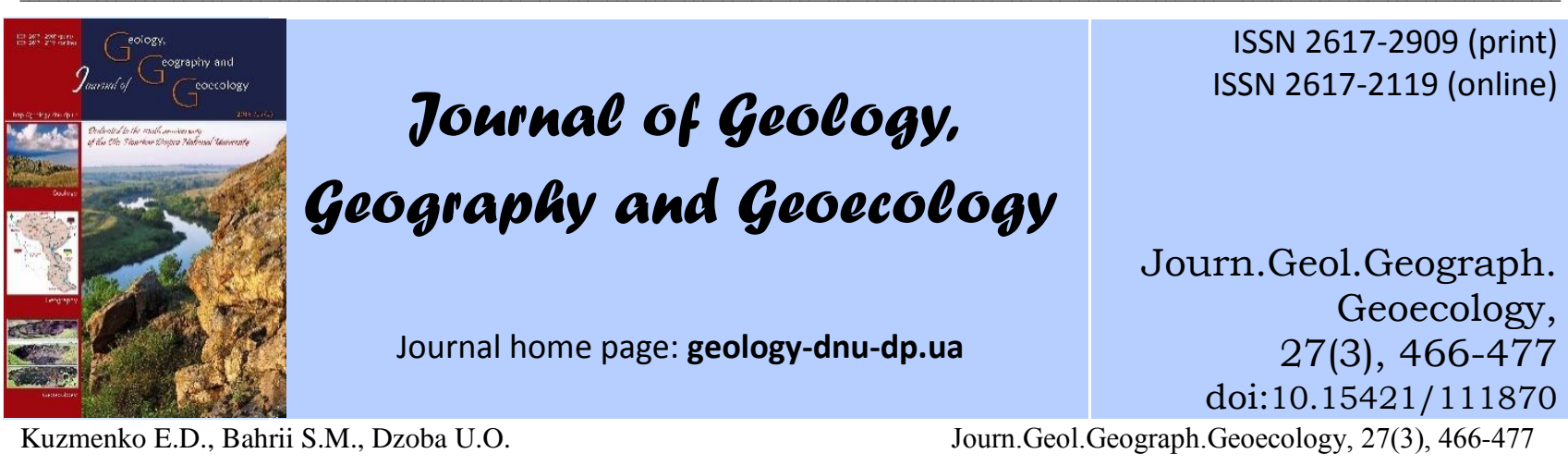

\title{
The depth range of the Earth'snatural pulse electromagneticfield (or ENPEMF)
}

\author{
Kuzmenko E.D., Bahrii S.M., Dzoba U.O.
}

Ivano-Frankivsk National Technical University of Oil and Gas, Ivano-Frankivsk, Ukraine, ulianadzoba@gmail.com

\section{Received 06.09.2018;}

Received in revised form 01.10.2018;

Accepted 03.10.2018

\begin{abstract}
On the basis of the analysis of the literature sources, we determined the possible range of using the method of the Earth`s natural pulse electromagnetic field. As a result of detailed analysis of domestic and foreign research, we demonstrated the relevance of conducting research focused on development of the Earth'snatural pulse electromagneticfield (or ENPEMF). Using the results of theoretical studies, the
\end{abstract} advantages and disadvantages of the ENPEMF method were determined. A complex of physical processes which preceded the development of the pulse electromagnetic field of the Earth was characterized, and the impact of mechanical deformations of rocks on the change in the condition of the electromagnetic field was experimentally proven. The main fundamentals on the determination of depth range of the ENPEMF method were examined and a new approach to interpretation of the data was suggested. We conducted an analysis of methods developed earlier of calculating geometric parameters of the sources which generate electromagnetic impulses. Their practicability at a certain stage of solving the data of geological tasks was experimentally tested. We determined the factors which affect the depth range of the ENPEMF method. A mathematical solution of the effectiveness of the ENPEMF method was suggested and determined the relations between the depth parameter of the study and the frequency of measuring and effective value of specific electric resistance. On the example of different objects, the effectiveness and correctness of the suggested method of determining the depth range parameter was proven. In particular, the theoretical results of the study were tested and confirmed on objects of different geological-morphological and engineering-technical aspects, i.e. Novo-Holyn mine in the Kalush-Holynske potash deposit and the multi-storey educational building of the University in Ivano-Frankivsk. The practicability of using the ENPEMF method in combination with other methods of electrometry for solving practical geological tasks was experimentally proven.

Keywords: The method of the Earth'snatural pulse electromagneticfield, depth range, stress-deforamtion condition.

\section{Глибинність методу природного імпульсного електромагнітного поля Землі}

Кузьменко Е.Д., Багрій С.М., Дзьоба У.О.

Івано-Франківський національний технічний університет нафти $i$ газу, Івано-Франківськ, Україна, ulianadzoba@gmail.com

\begin{abstract}
Анотація. На основі аналізу літературних джерел визначено можливий діапазон застосування методу природного імпульсного електромагнітного поля Землі. У результаті детального огляду вітчизняних та зарубіжних наукових праць, підтверджено актуальність проведення досліджень у напрямку розвитку методу ПІЕМПЗ. Використовуючи результати теоретичних досліджень, встановлено переваги та недоліки методу ПІЕМПЗ. Охарактеризовано сукупність фізичних процесів, що передують виникненню імпульсного електромагнітного поля Землі, та експериментально підтверджено вплив механічних деформацій гірських порід на зміну стану електромагнітного поля. Розглянуто основні положення щодо визначення глибинності методу ПІЕМПЗ та запропоновано новий підхід до інтерпретації даних. Проведено аналіз раніше визначених способів розрахунку геометричних параметрів джерел, що генерують електромагнітні імпульси. Експериментальним шляхом перевірено їх доцільність на певному етапі вирішення даних геологічних задач. Визначено чинники, що впливають на глибинність методу ПІЕМПЗ. Запропоновано математичне рішення щодо розв'язку питання глибинності методу ПІЕМПЗ та встановлено залежність параметру глибини дослідження від частоти вимірювання та ефективного значення питомого електричного опору.На прикладі різних об'єктів доведено ефективність та коректність запропонованого способу визначення параметру глибинності. Зокрема, теоретичні результати дослідження апробовані на різнопланових у геологічно-морфологічному та інженерно-технічному аспектах об'єктах, а саме руднику «Ново-Голинь» Калуш-Голинського родовища калійної солі та багатоповерховій будівлі навчального корпусу університету в місті ІваноФранківськ. Експериментально підтверджено доцільність застосування методу ПІЕМПЗ в комплексі з іншими методами електрометрії з метою вирішення прикладних геологічних задач.
\end{abstract}


Ключові слова: метод природного імпульсного електромагнітного поля Землі, глибинність, напружено-деформований стан.

Introduction. The method of the Earth'snatural pulse electromagneticfield (or ENPEMF) is a special geoelectronic method which over the recent years has become more and more widely used for solving geological-geophysical, engineeringecological, hydrogeological and other applied geological and geoinformational tasks. The theoretical basics of the ENPEMF method were first formulated by A. A. Vorobyev, who suggested the name of the method (Vorobyev, 1980). Electric fields in the bowels of the earth can form at high density of electric charges in dielectric rocks. The concentration of the charges occurs in a system with an excess of free energy. At different transformations, particularly, mechanical-electric, changes occur in the conditions of the rocks, so the minerals become the sources of electromagnetic radiation. Further studies of the ENPEMF method were conducted by V. M. Salomatin (Salomatin, 1987). He experimentally proved that the appearance of microdeformations in the rocks cause changes in stressed-deformed condition of the system and is a reason for the generation of electromagnetic signals.

Taking into account the multi-factor character of the processes which cause emission of electromagnetic field in the rocks, an important stage is correct interpretation of the results of research, one of the main aspects of which is determining the depth range of the ENPEMF method.

The ENPEMF method mostly makes it possible to allows perform a qualitative assessment of the condition of the environment and to obtain positive results from using it in combination with other geophysical methods, particularly, methods of electrosurvey - vertical electrical sounding (VES), transient electrical sounding (TS) and the method of gravity gradiometry.

The objective of the study was to characterize the main conditions for the determination of the depth range of the method, determining the factors which affect the depth range of ENPEMF, developing and applying new approach to the interpretation of the data.

Materials and methods. The ENPEMF method is based on recording the impulses of electromagnetic fields, generated by dielectric minerals in stressed condition. Over the recent decades, the ENPEMF method has become popular along with some other geophysical methods, due to its mobility, availability, speed and the relative cheapness of conducting the research. However, despite a number of advantages, one should take into account some disadvantages related to the nature of electromagnetic waves.
The physical nature of the processes which form electromagnetic impulses were described in the 1980 s by the eminent physicist A. A. Vorobyev (Vorobyev, 1980). He understood "the Earth's natural pulse electromagnetic field" to be electric charges which occur in different spheres of our planet, and also in the deep under the surface of the Earth, particularly in the structure of the rocks. Because the minerals which form the rocks are not homogenous and contain various additional substances, pores, chargeddislocations and other defects, in the presence of an external source of energy, tension develops in the structures and the systems become unbalanced and extra energy is formed. The processes which cause formation of electric impulses include: tensioning of the crystalline frame in the variable field of mechanical stresses, intense filtration of liquid in the capillaries and pores, relaxation of the stressed environment, presence of a double electric layer, and formation of plasma.

Taking into account that the stressed condition of rocks can occur as a result of different processes and phenomena and depend on a large number of factors at the same time, there is no unanimous theory of the ENPEMF for the moment. However, the studies by A. A. Vorobiev and V. M. Salomatin provide a broad range of experimental laboratory studies and the results of measuring ENPEMF in different geological conditions. V. M. Salomatin studied the pattern of mechanical-electric transformations depending on the mineralpetrophysical composition and structural peculiarities of rocks. The obtained results are a theoretical basis for the method and prove the assumption that at the stages of microdeformations, generation of electromagnetic pulses occurs, the intensity of which depends on the content of dielectric minerals, moisture, the extent of heating and density. Also, Salomatin elaborated the method of the application and was the initiator of using ENPEMF for the analysis of landslide danger zones (Salomatin, 1991).

The new principles of the system of processing the data of ENPEMF in the course of research on the stress-deformational condition of the rocks in landslide danger areas in Zakarpatia oblast are described in the works of Cheban V. D. (Cheban, 2002). Bezsmertnyy A. V. suggested using ENPEMF in combination with other geophysical methods for studying landslides on the southern coast of Crimea (Bessmertnyy, 2004). S. P. Kovalchuk precisely described the application of the ENPEMF and provided the results of analyzing the data on the landslides and the data on searching catacombs in Odessa oblast (Kovalchuk, 2003). 
Also, the question of applying the ENPEMF method in combination with other geophysical methods and predicting exogenous geological processes was studied by Kuzmenko E. D. (Kuzmenko, 2009). In his works, he suggests a calculation of a probability criterion for a prognostic assessment of landslide danger areas and proves the possibility of using geophysical methods for determining the stability of slopes with signs of landslide. Positive results of using the ENPEMF method were obtained during conducting a contour plan of underground galleries, mine workings and karst fractures (Kuzmenko, 2008).

Also, the literature contains data on a supplementary use of the ENPEMF method for searching the basins of hydrocarbon (Malyshkov, 2011) and describing the methods of interpreting ENPEMF anomalies related to occurrence of earthquakes (Hao, 2017).

However, domestic and foreign scientific sources contain practically no publications related to the aspects of the depth range of using the ENPEMF method .Accordingly, this circumstance provides relevance of further studies of these aspects and determines the main vector of our article.

Physical preconditions of the ENPEMF method. Because natural objects usually have a complex geological structure and history of formation, exactly determining the mechanism of mechanicalelectric transformations is impossible. Therefore, fundamental studies related to the Earth`s natural pulse electromagnetic field include the relationship between the intensity of the field for each parameter, which increases or reduces it, demonstrated at the qualitative level and the substantiation with a large empirical-experimental base correlated with general physical-mathematical fundamentals.

In his study, V. M. Salomatin (Salomatin, 1987) provides formulae which make it possible to calculate the phenomena and obtaining their characteristics. As already mentioned, in places of growing mechanical tensions, a concentration of charged defects occurs, the changes of which condition the occurrence of the charge and difference between the potentials. Free energy which depends on several independent variables can be expressed as follows:

$$
\begin{aligned}
& d F=a \cdot \varepsilon \cdot E^{2} d V+b \cdot \delta^{2} d V-S d T+ \\
& +V d P+M \cdot g d h+\left(\frac{d F}{d n_{i}}\right) d n_{i}+\ldots+(1) \\
& +\left(\frac{d F}{d n_{c}}\right) d n_{c}+\frac{d F}{d z} d z
\end{aligned}
$$

Where: $\varepsilon$ - dielectric penetrability of the substance;

$E$ - tension of electric field;

$V$ - volume of rock phase (solid or liquid);

$\delta$ - mechanical tension;

$a, b-$ constant coefficients;

$T$ - temperature in the Kelvin scale;

$S$ - entropy phase in dielectric rock;

$P$ - pressure;

$M, M g$ - mass and molecular weight of the phase in the rock;

$g$ - acceleration of the gravitational force;

$h$ - height of the location of the phase in the gravitational field;

$z$ - size of the grains of the phase in the rock;

$S, V, M g$ - partial derivatives $\frac{d F}{d T}, \frac{d F}{d P}, \frac{d F}{d n} ;$

$\frac{d F}{d n_{i}}$ - change in the free energy phase,

related to the change in the chemical composition per one mol $i$ - that element of the phase;

$\frac{d F}{d n_{c}}$ - change in the free energy, related to the change in the phase concentration;

$\frac{d F}{d z}$ - change in the free energy, related to the change in grains of the phase.

As a result of the impact of various factors, the signals combine, i.e. field overlap. They are generated by different sources. Regardless of the mechanism of generation, in the reception point, a total signal is obtained, the value of which, with consideration of the reduction, is determined using the formula:

$$
E=\sqrt{\frac{V}{m} \cdot \beta} \cdot \frac{E_{0} \cdot \lambda}{2 \cdot \pi \cdot c} \cdot\left(\frac{r}{R}\right)^{3} \cdot \Delta W,
$$

where $E_{0}$ - amplitude of the tension of the field on the borders of diffusive layer;

$\lambda$ - wave length;

$R$ - distance between the receptor and the emitter;

$c$ - speed of light;

$\Delta W$ - frequency range of the reception;

$V$ - the radiating volume of the rocks;

$m$ - volume of the elementary emitter;

$\beta$ - zone of the emitter in the volume the rocks;

$r$-typical size of the emitter.

Formulae 1 and 2 give a general impression on the multi-functional character of the process of formation of electromagnetic radiation. They cannot be an analytic basis for solving a direct or an inverse problem of geophysics. No such formulae 
for the ENPEMF exist at all. Therefore, we should consider the ENPEMF method as a qualitative method based on comparing geological processes and the corresponding explanations of the change in electromagnetic field according to the principle "more-less".

Among the fundamental studies in the sphere of geological nature of the potentials of the electric field in the Earth`s crust, we should mention the studies by B. G. Tarasov and his students (Tarasov, 1989). The best work in theoretical substantiation is the article by Ivanov (Ivanov, 1991) .

The main idea is that stationary gradient geomechanical fields can contain currents (also stationary) of charged defects of the structure anion or cation vacancies, clusters, i.e. microcavities composed of the vacancies of one or the other electric charge and dislocations on which the charged steps are located. Such process is called an orientated diffusion of the defects. In the condition of thermodynamic balance, the charged centers are compensated by the opposite electric charges, i.e. the field is absent. After tension is applied, imbalance occurs between the charges due to the oriented transport of the defects and their separation from the charge-compensating cloud, therefore diffusive currents of charged defects with electric tension occurs, to which a certain electric potential corresponds.

Further, on the basis of the fundamental equations of solid body physics, the following formula (3) was obtained, which describes the effect of relations of the potential and geomagnetic tension and the generality of this law for all rocks:

$$
\varphi=\frac{\left(-\Omega_{0}\right) \cdot \sigma \cdot f}{3 \cdot q},
$$

where $\varphi$ - mechanical-electric potential;

$\sigma-$ mechanical tension;

$f$ - entropic coefficient;

$q$ - charge transmitted by one vacancy.

The simple equation (3) shows that the effect is determined by the structure of diffusing defects and their charge, and also the value of active mechanical tension.

$$
\begin{aligned}
& \text { Quantitative calculation provides: } \\
& \Omega_{0}=\left(3 \cdot 10^{-10}\right)^{3} \mathrm{~m}^{3} ; \quad \sigma=50 \cdot 10^{6} \mathrm{~N} / \mathrm{m}^{2} ; \\
& f=10 \ldots 10^{4} ; q=1,6 \cdot 10^{-19} \mathrm{Kl}, \text { then we obtain } \\
& \varphi=(27 \ldots 2700) \cdot 10^{-3} \mathrm{~V} .
\end{aligned}
$$

Thus, for all considered ionic crystals, the effect is no higher than $2.7 \mathrm{~V}$. Towards the depth of the bedding of the rocks, the potential undergoes a linear increase, i.e. the crust always contains currents conditioned by the pressure gradients, which must penetrate the entire layer of rocks in accordance to the expression $\varphi=\varphi_{0}+k_{m-e} \cdot \sigma$, where $\varphi_{0}$ - initial value of the potential on the Earth`s surface; $k_{m-e}$ - coefficient of mechanicalelectrical transformations.

In common understanding, according to the hydrostatic hypothesis $\sigma=\gamma \cdot H$, where - $\gamma$ is volumetric weight of the rocks, $\mathrm{N} / \mathrm{m}^{3}, H$ - depth at which the geomechanical tension is considered, $\mathrm{m}$, anomalies of geomechanical pressures lead to anomalies of the potential in accordance with the anomalies of pulse electromagnetic radiation.

Due to the indeterminacy of the entropic coefficient which depends on the types of transformations and physical properties, the formula (3) for solving direct and inverse problems of electrometry is inapplicable.

The depth range of ENPEMF. General thoughts. Taking into account that the notion of "the Earth's natural pulse electromagnetic field" is quite complex and includes different types of radiation (including that generated by rocks), in the context of determining the effectiveness of the method, one should also consider magnetotelluric variations. A magnetotelluric field is a regional part of the variable electromagnetic field of the Earth and consists of a telluric (electric) and magnetic field. Changes in this field over time are considered magnetotelluric variations (Khmelevskoy, 1989) .

V. D. Cheban in his studies suggests a hypothesis that the radiation of the natural pulse electromagnetic field caused by deformations of rocks travels the same route as the magnetotelluric waves which penetrate the Earth, but in the opposite direction (Cheban, 2002). Because these radiations have the same electromagnetic nature, in this article we assume that the distance which the electric waves penetrating the Earth travel can be used also for the calculation of depth of the possible source of the electromagnetic field.

The depth of penetration of magnetotelluric field, i.e. the thickness of the skin-layer is the distance at on which the wave amplitude fades in $e$ times (Khmelevskoy, 1989):

$$
\delta=\frac{\lambda}{2 \cdot \pi}=\sqrt{\frac{2 \cdot \rho}{\omega \cdot \mu_{0}}},
$$

where $\rho$ - specific electric resistance $[\Omega \cdot \mathrm{m}]$, $\omega=2 \cdot \pi \cdot f, \quad \mu_{0}=4 \cdot \pi \cdot 10^{-7} \mathrm{H} / \mathrm{m}$ (in the study by Khmelevskoy, 1989) V. K. Khmelevskoy studied the section of a one-dimensional geological model, where the specific resistance is a constant function and considers the magnetic penetrability as a constant value which equals $\mu_{0}=4 \cdot \pi \cdot 10^{-7} \mathrm{H} / \mathrm{m}$ ).

Effective depth of penetration of the field into a one-dimensional medium which is at stable 
electric resistance can be calculated according to the formula

$$
h_{c p}=\frac{\delta}{\sqrt{2}}=\sqrt{\frac{\rho}{\omega \cdot \mu_{0}}} .
$$

Because the length of electromagnetic wave depends on the wave value $k$, then

$$
\lambda=2 \cdot \pi \cdot \sqrt{2} \cdot|k|=2 \cdot \pi \cdot \sqrt{\frac{2 \cdot \rho}{\omega \cdot \mu_{0}}} .(6)
$$

After change of variables, we obtain the formula, where the length of electromagnetic wave

$$
\lambda=\sqrt{\frac{10^{7} \cdot \rho}{f}},
$$

Where $f$ - frequency in $\mathrm{Hz}$.

Thus, after the transformation, we obtain :

$$
h_{e \phi}=\frac{\sqrt{10^{7} \cdot \rho}}{2 \cdot \pi \cdot \sqrt{2 \cdot f}} \cdot 10^{3}=356 \sqrt{\frac{\rho}{f}} .
$$

In this case, the effectiveness of ENPEMF will depend on the frequency range and geological environment. The technical properties of a RHINDC-PM (radiowave indicators of stress deformed condition) device allow one to work within a range of from 2 to $50 \mathrm{kHz}$.

Because an environment cannot be homogenous, we suggest calculating the efficient value of the specific electric resistance for a particular layer of the rocks. Effective resistance is determined using formula:

$$
\rho_{e \phi}=\frac{h_{1}+h_{2}+\ldots+h_{n-1}}{\frac{h_{1}}{\rho_{1}}+\frac{h_{2}}{\rho_{2}}+\ldots \frac{h_{n-1}}{\rho_{n-1}}} .
$$

As an example, we will consider a geological model for which the value of the specific electric resistance equals $10 \Omega \cdot \mathrm{m}$. After the calculations according to the formula (8) are made, we find that the possible source of electromagnetic radiation can be at the depth from 5 to $25 \mathrm{~m}$. Therefore, as the effective electric resistance increases, the deeper is the range of the ENPEMF method, and by changing the frequency range, we will obtain signals from different depths.

Results and their analysis. Determination of depth range for different objects. Let us consider the area of the worked out Novo-Holyn mine of the Kalush-Holynske potash deposit, which is located in the Precarpathian Trough. From 1867 to 1995 in the Kalush-Holynske deposit, the mineral substance was excavated using two methods: open-pit and underground mining. The open-pit mining was used in the Dombrovsky Quarry which after its operation has the capacity of around $52 \mathrm{M} \mathrm{m}^{3}$. The cavities of mines Kalush $\left(7.4 \mathrm{M} \mathrm{m}^{3}\right)$, Novo-Holyn $\left(12.1 \mathrm{M} \mathrm{m}^{3}\right)$ and Holyn $\left(1.7 \mathrm{M} \mathrm{m}^{3}\right)$, which became worked out and were taken out of the operation, were only partly filled with solid material in separate ore fields ( $92.5 \%$ of the total capacity of the cavities) or remained dry ( $7.5 \%$ of the volume). Most cavities, and particularly all mining chambers of the NovoHolyn mine were filled with insufficiently saturated brine (7.2\% of the volume) (Bahrii, 2013).

Such method of filling is not reliable and cannot guarantee the safety of the rock structure and stability of the interchamber bearing blocks and ceilings. As a result, subsidence of the Earth's surface occurs accompanied by following flooding and formation of collapsing craters. Part of the territory of Kalush and the surrounding villages with a population of a few thousand people are within the zone of risk. Therefore, a decision was made to perform topographic-geodesic and geophysical studies for ascertaining of the fact of subsidence and forecasting it over time and space.

To solve the problems, we measured using methods of electrometry VES and TS, and also for the study of tension-deformational condition of rock structure, we conducted a detailed survey of the ENPEMF.

Due to the insignificant depth range, in Kalush-Holynske mine, the VES method was used for determining the lithological composition of the Quaternary formations and their thickness, and also the extent of salinization of the groundwater due to surface sources of pollution (tailing dams, potash salt dumps and accumulating reservoirs) (Bahrii, 2013).

In the context of determining the depth range of the ENPEMF method, the VES method is extremely important for it allows one to determine the pre-surface geological section of the studied layers with sufficient accuracy and to calculate the effective value of the specific electric resistance.

The study of the stress-deformed condition of rock structures allows one to identify danger zones and draw conclusions on the reliability of interchamber bearing blocks and ceilings.

Analyzing the geological and geoelectrical sections, we conclude that in front of the ceiling of the upper horizon of the chamber, five geoelectric horizons are present, as demonstrated in Table 1.

Let us determine the effective resistance:

$$
\rho_{e \phi}=\frac{0,6+11+9+18+80}{\frac{0.6}{218}+\frac{11}{29}+\frac{9}{76}+\frac{18}{9}+\frac{80}{275}}=42.49(\Omega \cdot \mathrm{m})
$$

After calculating the effective resistance, we can determine the depth range of the method of the Earth`s natural pulse electromagnetic field for a certain range of frequencies using the formula (8).

$$
\text { At frequency } f=2000 \mathrm{~Hz} \text {, the depth }
$$
equals $h_{e f}=51.89 \mathrm{~m}$, at frequency $f=50000_{\mathrm{Hz}}$, the 
depth $-h_{e f}=10.37 \mathrm{~m}$. That is for the present range,

measured approximately.

the depth range of the ENPEMF method can be

Table 1. Geolectric horizons according to the data of electrometry

\begin{tabular}{|c|c|c|c|}
\hline$№$ & Thickness of the horizon, $\mathrm{m}$ & $\begin{array}{c}\text { Electric resistance of the } \\
\text { horizon, } \Omega \cdot \mathrm{m}\end{array}$ & The rock, horizon is represented by \\
\hline 1 & $h_{1}=0.6$ & $\rho_{l}=218$ & Soil-plantcover \\
\hline 2 & $h_{2}=11$ & $\rho_{2}=29$ & Loam \\
\hline 3 & $h_{3}=9$ & $\rho_{4}=76$ & Gravel-pebblehorizon \\
\hline 4 & $h_{4}=18$ & $\rho_{4}=9$ & Gypsum-clayhorizon \\
\hline 5 & $h_{5}=80$ & $\rho_{5}=275$ & Saliferous breccia \\
\hline
\end{tabular}

The question arises of whether it is possible to determine the depth range of the method, first of all, for more particular conditions, and, secondly, with provision of empirical-functional dependency of changes in characteristics of geological section at electric resistances and thicknesses of strata.

For the assessment of real changes in the depth range of the ENPEMF method in particular geological conditions, let us imagine the geological model demonstrated in Table 1. Because the thicknesses of the strata of the gypsum-clayey cap and saliferous breccia is unstable, i.e. can change within a geological section, this model is inappropriate in the sense that the depth of bedding of the horizons is not indicated for $h_{4}$ and $h_{5}$. In fact, we have a system of three equations solving at the same time:

$$
\left\{\begin{array}{l}
\rho_{e \phi}=\frac{h_{1}+h_{2}+\ldots+h_{n-1}}{\frac{h_{1}}{\rho_{1}}+\frac{h_{2}}{\rho_{2}}+\ldots \frac{h_{n-1}}{\rho_{n-1}}} \\
H=h_{1}+h_{2}+\ldots+h_{n-1} \\
H=7,96 \cdot \sqrt{\rho_{e \phi}}
\end{array}\right.
$$

The latter formula of the system is obtained from the formula (8) at the value $f=2000 \mathrm{~Hz}$. At the same time, the conditions should be:

$$
\left\{\begin{array}{l}
h_{4}>0 \\
h_{5} \geq 0
\end{array}\right.
$$

This is explained by the possibility of increasing or decreasing of the thickness of gypsum-clayey cap in the absence or presence of a certain saliferous breccia in the section before a certain depth. Increase in the thickness of the gypsum-clayey cap leads to decrease in the thickness of saliferous breccia involved in the calculation of $\rho_{e f}$.In general, this changes the depth range of the ENPEMF method. At the same time, it is clear that with decrease in the thickness of the gypsum-clayey cap (GCC) with distinctive low resistance and corresponding increase in thickness of saliferous breccia with comparatively high electric resistance, the value of effective resistance involved will increase. Accordingly, the effective depth of the survey using the ENPEMF will increase.

Factual data are demonstrated in Table 2. Quantitative characteristics demonstrated in the table were used for the analysis of change in effective depth during study of the ENPEMF. Further, let us consider the stages of determining the given geoelectric parameters and the corresponding dependencies.

Table 2. The initial data and depth range of ENPEMF method

\begin{tabular}{|c|c|c|c|c|}
\hline № & $\begin{array}{c}\text { Thicknessofgypsum- } \\
\text { clayeycap } \\
H_{g c c} \mathrm{~m}\end{array}$ & $\begin{array}{c}\text { Thickness of saliferous } \\
\text { breccia } h_{s b}, \mathrm{~m}\end{array}$ & $\begin{array}{c}\text { Effective resistance } \\
\text { of rocks } \rho_{e f}, \Omega \cdot \mathrm{m}\end{array}$ & $\begin{array}{c}\text { Depth of } \\
\text { surveyH,m }\end{array}$ \\
\hline 1 & 12 & 0 & 17.7 & 33.5 \\
\hline 2 & 11 & 2.9 & 19.9 & 35.5 \\
\hline 3 & 10 & 6 & 22.4 & 37.7 \\
\hline 4 & 9 & 9.5 & 25.47 & 40.1 \\
\hline 5 & 8 & 13.1 & 29.01 & 42.9 \\
\hline 6 & 7 & 17.2 & 33.41 & 46.0 \\
\hline 7 & 6 & 21.5 & 38.62 & 49.4 \\
\hline 8 & 5 & 26.5 & 45.21 & 53.5 \\
\hline 9 & 4 & 32 & 53.33 & 59.9 \\
\hline 10 & 3 & 38.1 & 63.45 & 63.4 \\
\hline 11 & 2 & 45 & 76.2 & 69.5 \\
\hline
\end{tabular}


It is clear that the primary cause of the change in the depth range of the ENPEMF is the change in thickness of the GCC, which leads to the change in equivalent resistance used in calculations of the specific electric resistance and therefore the effective depth.

First of all, as the thickness of the GCC increases, the thickness of the stratum of saliferous breccias decreases. Because the electric resistance of the cap is much lower than the resistance of the saliferous breccia, the value of the equivalent resistance at the same time decreases (Fig. 1a). Accordingly, at increase of the thickness of saliferous breccia, the equivalent resistance increases (fig. 1b). The graph between the total thickness of the rocks and equivalent electric resistance (Fig. 1c) is the result of processing the dependencies Fig. 1a-1b.

Graphs in Fig. 1 are the reason for graphic depiction of the abovementioned formulae on determination of dependency of the effective depth of the ENPEMF on the thicknesses of gypsumclayey cap, used in the calculations, saliferous breccias and their total thickness (Fig. 2a, 2b, 2c).

The graph demonstrated in Fig. 3 sums up the functional-empirical result of the dependency of

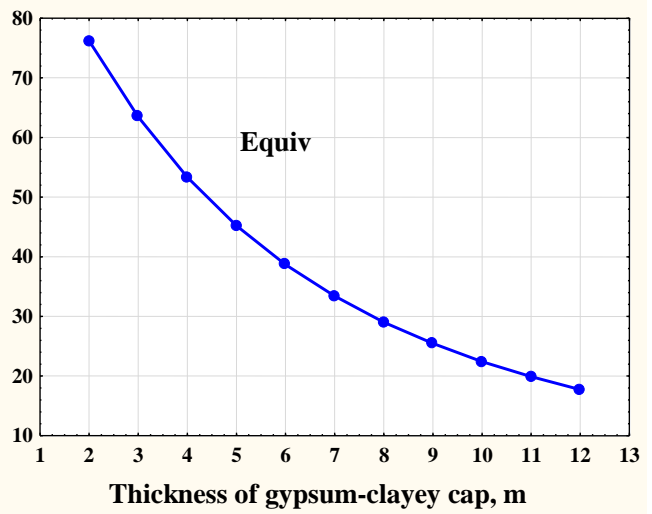

effective depth of survey on the change in equivalent resistance.

Thus, maximum depth of the ENPEMF for this object is about $70 \mathrm{~m}$. This is enough for studying the processes of development of salt karst, washout and destruction of saline breccia and therefore the horizons above. At the same time, one can study the upper row of extraction chambers. The impact of deformation of the rocks on the pulse electromagnetic field on greater depths is monitored indirectly, through mechanical interaction of other horizons.

A clear example is the graphs of the ENPEMF for a geological section which includes a stratum of salt and excavating chamber (Fig. 4). The graph in Fig. 4a demonstrates two expressions of the anomalies of the field intensity, which correspond to mechanical tensions in border prewall zones of excavation, which border with ceilings. The anomaly in Graph $4 \mathrm{~b}$ correlates with change of tensions above the ceiling of the chamber. Deformational zones are on absolute points near $230 \mathrm{~m}$ at points of the Earth`s surface of $300 \mathrm{~m}$. Thus, $70 \mathrm{~m}$ depth correlates with previous calculations and their analysis (Fig. 3).

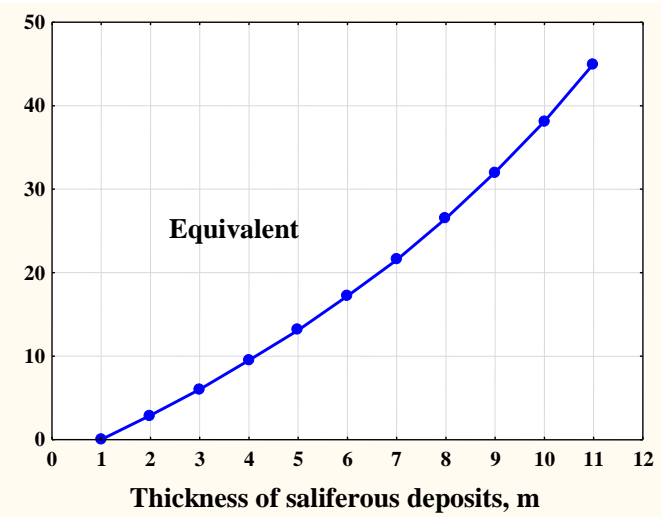

a)

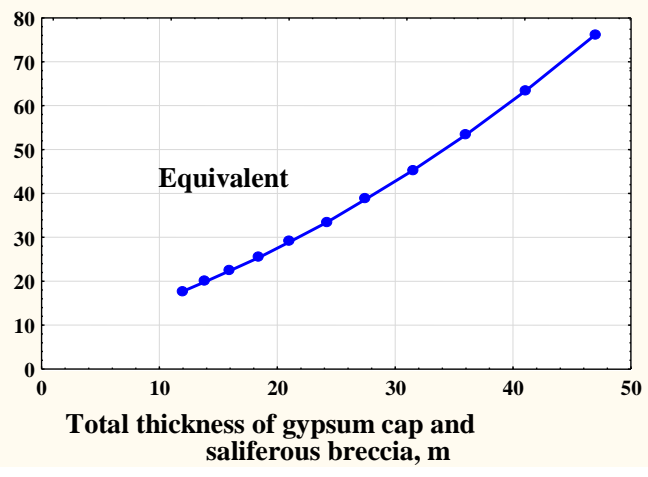

b)

c)

Fig. 1. Graph of dependency of the equivalent resistance on the thickness of the rocks: a) gypsum-clayey cap; b) saliferous breccias; c) total thickness of GCC and saliferous breccia. 
Also, at this stage of the study, we considered another method of determining the depth range. In the monograph (Bessmertnyy, 2004), the author mentions that for determining geometric parameters of the source of stress-deformational condition of the rocks, one should take into account the magnetic component of the secondary electromagnetic radiation. That is for determining the depth of bedding of an object which generates

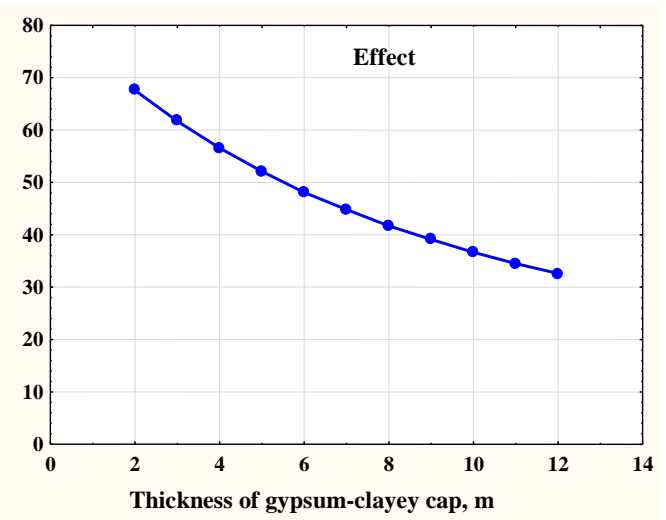

impulses, one should solve an inverse problem of magnetic survey. After analysis of the type of anomalies and defining the distinctive points, one can determine the geometric parameters of the sources of stress-deformation condition. Because the determined depth is not proved by the geological information, it was determined that at this stage of study, such approach to determine the depth is incorrect.

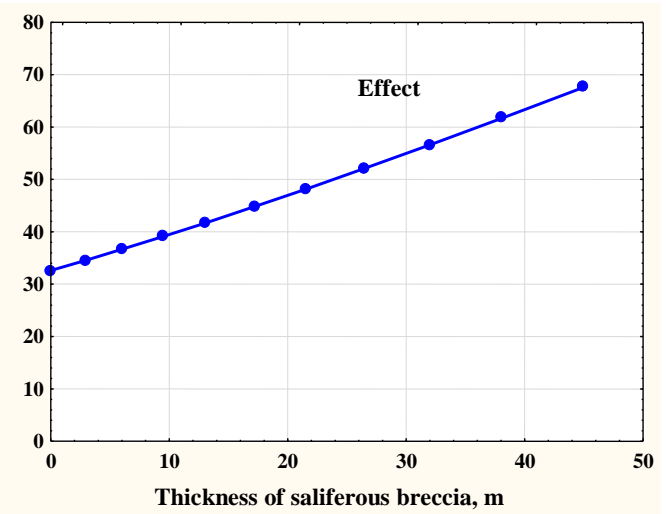

a)

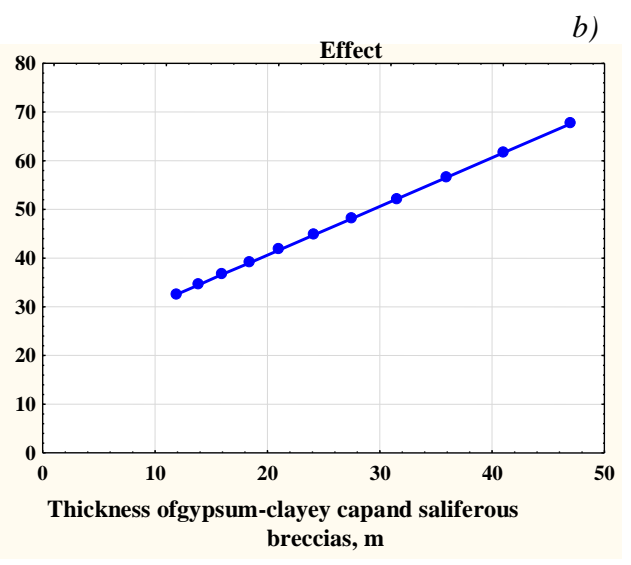

c)

Fig. 2. Graphs of dependency of effective depth of the ENPEMF on the thickness of the rocks: a) gypsum-clayey cap; b) saliferous breccias; c) total thickness of GCC and saliferous breccias.

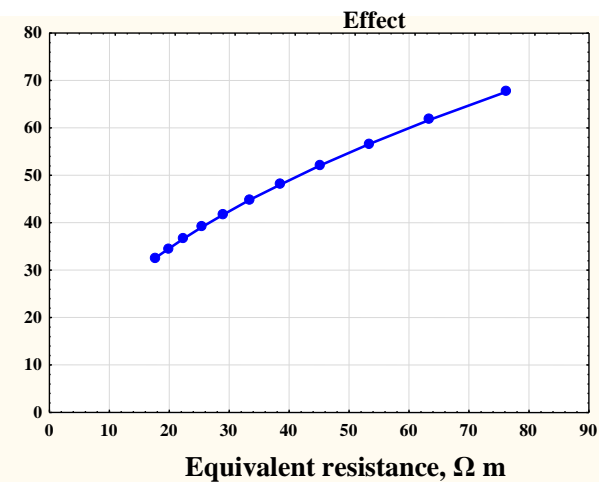

Fig. 3. Graph of dependency of effective depth of survey on the equivalent resistance 
Also, at this stage of the study, we considered another method of determining the depth range. In the monograph (Bessmertnyy, 2004), the author mentions that for determining geometric parameters of the source of stress-deformational condition of the rocks, one should take into account the magnetic component of the secondary electromagnetic radiation. That is for determining the depth of bedding of an object which generates

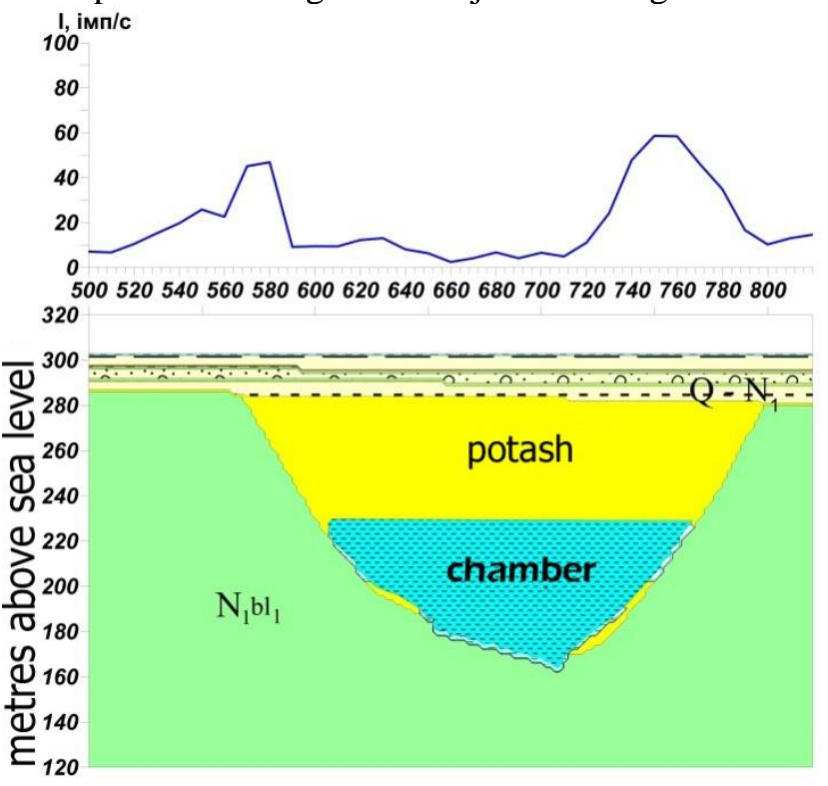

a)

Fig. 4. Geological section and graphics of the ENPEMF

The next object studied in this work is Building №1 of Ivano-Frankivsk National Technical University of Oil and Gas, where the first stage of geophysical studies was conducted in the period from $11^{\text {th }}$ May to 3 June 2016. The preconditions for conducting geophysical work were presence of fractures in the zones adjoining the staircase and within the ceiling of the semibasement and deformation of the external selfsupporting wall.

The objective of the studies was to determine the geological structure of this area and characterize the intensity of radiation of the Earth's natural pulse electromagnetic field. The methods of study: vertical electrosounding (VES), measuring using the ENPEMF.

The result of interpretation should answer the question of reliability of the rock stratum on which the foundations of the Building №1 are located impulses, one should solve an inverse problem of magnetic survey. After analysis of the type of anomalies and defining the distinctive points, one can determine the geometric parameters of the sources of stress-deformation condition. Because the determined depth is not proved by the geological information, it was determined that at this stage of study, such approach to determine the depth is incorrect.

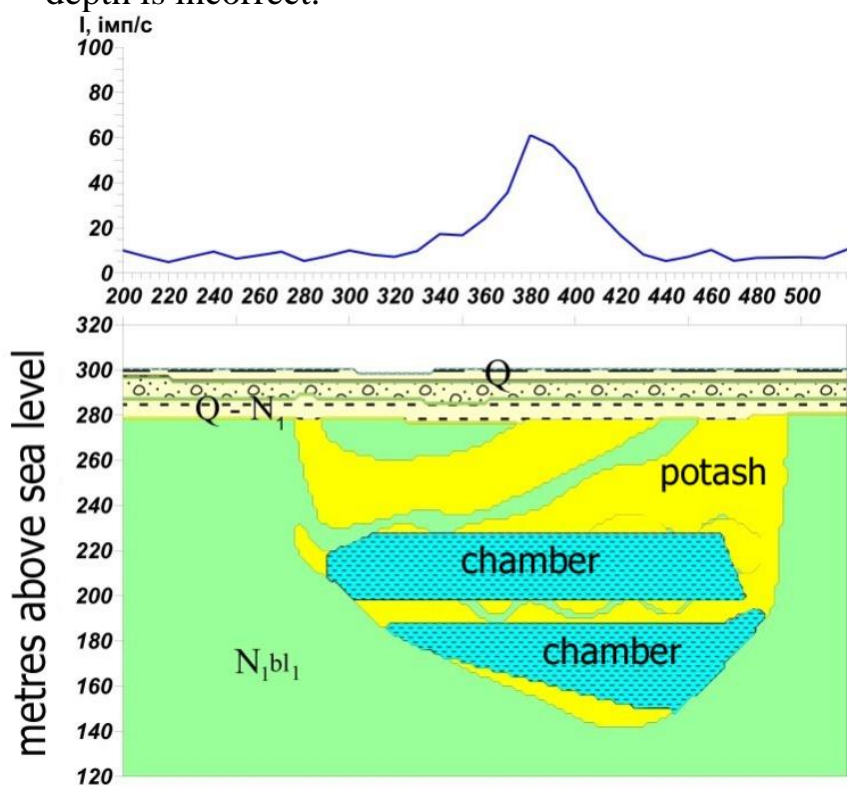

b)

from the perspective of engineering stability and safety of using the building.

The depth range of the VES method depends on the length of lines of the current. For developing a necessary geoelectric section with consideration of extent of building development of the territory, we selected the maximum distribution of the current line $-130 \mathrm{~m}$. This allowed us to provide a depth range of the studies of around $15 \mathrm{~m}$. As a result of vertical electrosounding, a curve was obtained, which corresponds to a five-layer geoelectric section with the proportion of electric resistances $\rho_{1}<\rho_{2}>\rho_{3}>\rho_{4}<\rho_{5}$. For interpreting, we used the program complexes VEZ and IPI2WIN. The results of interpreting in correspondence to these program complexes are demonstrated in Table 3. In the formalized interpretation, the strata $\rho_{2}$ and $\rho_{3}$ are combined in one stratum.

Table 3. Generalization of the results of VES interpretation

\begin{tabular}{|c|c|c|c|}
\hline \multirow{2}{*}{$\begin{array}{c}\text { № } \\
\text { of strata }\end{array}$} & \multirow{2}{*}{ Sign of strata } & \multicolumn{2}{|c|}{ VES results } \\
\cline { 3 - 4 } & & Resistance & Thickness \\
\hline 1 & $\rho_{1}$ & 95 & 0.71 \\
\hline 2 & $\rho_{2-3}$ & 335 & 3.35 \\
\hline
\end{tabular}




\begin{tabular}{|c|c|c|c|}
\hline 3 & $\rho_{4}$ & 3.05 & 4.63 \\
\hline 4 & $\rho_{5}$ & 7.5 & $\infty$ \\
\hline
\end{tabular}

In correspondence with the literature data on the geolelectric section of the Precarpathian Trough and the results of research by the authors of the article, we determined the rocks which form the layers. The detailed characteristics of geoelectric horizons of the section are as follows: horizon I soil layer composed of soil, sandy loam and loam, dehydrated in the period of the study, average thickness $-0.71 \mathrm{~m}$, apparent electric resistance -95 $\Omega \cdot \mathrm{m}$, age - late Quaternary Period; horizon II pebble horizon with sandy filling, visually observed on the shore of the Bystrytsia river, dry for the period of the study, thickness - 1.3-1.8 m, electric resistance $-335 \Omega \cdot \mathrm{m}$, age - late Quaternary Period; horizon III in lithology is an analogue of horizon II, is different by being embedded lower than the level of groundwater, thickness - 1.6-2.1 m, electric resistance $-23 \Omega \cdot \mathrm{m}$, age - late Quaternary Period; horizon IV - layer of fine-dispersed flexible humid clay, the origin of which has no certain explanation: possibly lagoonal deposits, or glacial formations, or the result of erosion of Quaternary sandy loam and clay, thickness $-4.6 \mathrm{~m}$, electric resistance -3.1 $\Omega \cdot \mathrm{m}$, age - Quaternary Period, horizon V consolidated sandy loam, thickness - from $5 \mathrm{~m}$, electric resistance $-7.5-23 \Omega \cdot \mathrm{m}$.

On the basis of the obtained data, we determined the effective value of specific electric resistance:

$$
\rho_{e \phi}=\frac{0.71+3.35+4.63+1.31}{\frac{0.71}{95}+\frac{3.35}{335}+\frac{4.63}{3.05}+\frac{1.31}{7.5}}=5.84(\Omega \cdot \mathrm{m})
$$

The ENPEMF method was applied in a profile variant with the purpose of determining the zones of stress-deformation condition, where mechanical shifts occur. The profiling was performed for three profiles in the frequency range of $2-50 \mathrm{kHz}$, i.e. intensity of the field is integrated for mentioned limits of the frequencies. The points on the profiles were located under the walls of the building in such way that the device was literally touching the walls. The measuring was made for directions $\mathrm{X}, \mathrm{Y}, \mathrm{Z}$. At the same time, the $\mathrm{X}$ direction was selected in such way that the aerial was directed towards the wall of the building, direction $\mathrm{Y}$ - so the aerial was parallel to the wall of the building, and the direction of aerial $\mathrm{Z}$ - in perpendicular to the ground surface. The positions of the profiles and the results of the measuring of the ENPEMF are demonstrated in Fig. 5.

Profile 1 was also processed for different ranges of frequencies, particularly: $2-16 \mathrm{kHz}$ and
$16-36 \mathrm{kHz}$ for all three directions of the aerials. The change in the frequencies was made for dividing the thickness of the rocks according to stress-deformation condition on different depths and detailing the results. As we see, the highest values of the field were recorded for the complete range of frequencies $(2-50 \mathrm{kHz})$. For range 2-16 $\mathrm{kHz}$, the value was the lowest, that is stressdeformation condition to a higher extent corresponded to the range $16-36 \mathrm{kHz}$.

After using the values of effective resistance, we calculate the depth range of the ENPEMF method for different frequencies using formula 8 . At $f=2000 \mathrm{~Hz}$, depth equals $h_{e f}=19.23 \mathrm{~m}$, at $f=$ $16000 \mathrm{~Hz}$, depth is $h_{e f}=6.8 \mathrm{~m}$, at $f=36000 \mathrm{~Hz}$, depth is $h_{e f}=4.53 \mathrm{~m}$, at $f=50000 \mathrm{~Hz}$, depth is $h_{e f}=$ $3.84 \mathrm{~m}$.

The first layer from the surface of the soil is the layer of pebble rocks which are the Bystrytsia deposits. The thickness of this horizon is no less than $3.6 \mathrm{~m}$. Groundwater covers the lower part of the horizon and contributes to the washout of sand fraction from it. Under the pebble horizon, there is a moistened flexible clay with anomalously low values of electric resistance and therefore with low values of density parameters. Any load will deform this layer. Clay is vulnerable to washout.

The analysis of the intensity of pulse electromagnetic radiation indicates the presence of a significant anomaly of radiation, which is territorially adjacent to the western angle of the building (where the fracture is seen). This allows us to state that over the time of the study, active stage of deformation of the rocks was taking place under the impact of non-uniform pressure of the building`s structure.

Because the anomalous field is formed mainly by the signals obtained on high frequencies, in this case, the depth range of the ENPEMF method can be limited within intervals of 5-7 m, which in geological aspect coincides with the base surface of the clay horizon.

Conclusions. On the basis of analysis of quantitative scientific sources, the promising perspective of using the ENPEMF method for determining and localizing zones of stressdeformation condition of rocks was proven. This is especially relevant for solving a broad range of engineering-geological tasks. The results of generalized theoretical studies conducted by different authors have made it possible to determine the advantages and disadvantages of the ENPEMF method. 
The unity of physical process prior to the formation of the Earth's pulse electromagnetic field was characterized, and the impact of mechanical deformations of the rocks on the change in the condition of the electromagnetic field was experimentally proven.

A mathematical solution to the problem of depth range of the ENPEMF method was suggested and the dependency between the parameter of depth of research and frequency of measuring and effective electric resistance was determined.

The obtained theoretical dependencies were tested and confirmed for several different objects. In particular, we demonstrated the usage of the approach for solving the problem of depth range of the ENPEMF method in the area of the NovoHolyn mine of the Kalush-Holunsk potash deposit with the aim of safeguarding against further subsidence, and near Building №1 of IvanoFrankivsk National Technical University of Oil and Gas for preventing its ruination.

The conducted experimental studies proved the practicability of using the ENPEMF method in combination with other methods of electrometry for assessing the risk of development of exogenous geological processes. 


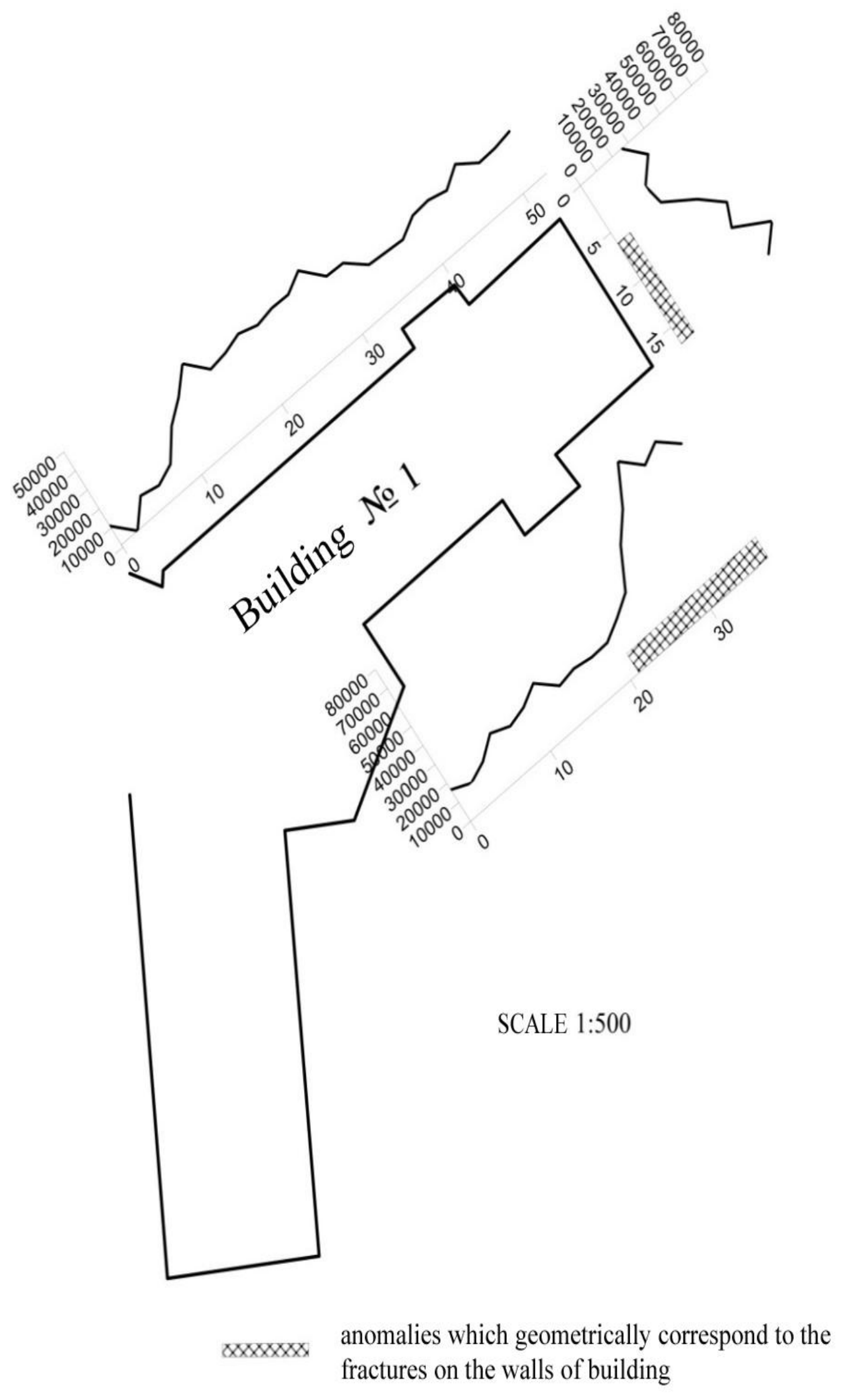

Fig. 5. Measures of ENPEMF in range of frequencies 2-50 kHz 


\section{References}

Bahrii, S. M., Kuzmenko, E. D., 2013. Do pytannia otsinky zabrudnennia pidzemnykh vod elektrometrychnymy metodamy [On the issue of assessing the pollution of groundwater by electrometric methods].Geodynamics, №2 (15), 93-96 (in Ukrainian).

Bessmertnyy, A. F., 2004. Kompleksnyye geofizicheskiye issledovaniya opolzney i postroyeniye prognoznykh modeley ikh aktivnosti (na primere Yuzhnogo berega Kryma) [Complex geophysical studies of landslides and the construction of predictive models of their activity (on the example of the Southern coast of Crimea)].PhD Thesis. Simferopol (in Russian).

Cheban, V. D., 2002. Kompleks heofizychnykh metodiv prohnozuvannia zsuviv na prykladi Zakarpattia [Complex of geophysical methods of forecasting landslides on the example of Transcarpathia]. PhD Thesis. IvanoFrankivsk (in Ukrainian).

Hao, G. C., Bai, Zhao, Y. J., Wu, M., Yang, Y., 2017. A receiving instruments of the Earth's natural pulse electromagnetic field and its data analysis via time-frequency method before an earthquake. IEEE International Instrumentation and Measurement Technology Conference (I2MTC). Turin, Italy.

Ivanov, V. V., Tarasov, B. G., Kuzmenko, E. D., Gordiychuk, N. V., 1991. O geomekhanicheskoy prirode potentsialov elektricheskogo polya $\mathrm{v}$ zemnoy kore [Geomechanical nature of the potentials of the electric field in the earth's crust]. Izv.VUZov. Geologiya i razvedka, N3. 101-104 (in Russian).

Khmelevskoy, V. K., Bondarenko V. M.,1989. Elektrorozvedka: Spravochnik geofizika. V dvukh knigakh [Electrical prospecting: Handbook of Geophysics]. Nedra (in Russian).

Kovalchuk, S. P., 2003. Postav svoy dom pravilno (Praktika geofizicheskogo metoda EIEMPZ) [Place your house correctly]. Chernomorye, Odessa (in Russian).

Kuzmenko, E . D., Bezsmertnyi, A. F., Vdovyna, O. P., Kryviuk, I. V., Cheban, V. D., Shtohryn, L. V., 2009. Doslidzhennia zsuvnykh protsesiv heofizychnymy metodamy [Investigation of landslide processes by geophysical methods]. IFNTUNH, Ivano-Frankivsk (in Ukrainian).

Kuzmenko, E. D., Kryviuk, I. V., Shtohryn, M. V., 2008. Rezultatyvnist heofizychnykh metodiv pry okonturenni pidzemnykh halerei [The effectiveness of geophysical methods for detection of underground galleries]. Materialy naukovoi konferentsii «Heofizychni tekhnolohii prohnozuvannia ta monitorynhu heolohichnoho seredovyshcha». NAN Ukrainy, Karpatske viddilennia Instytutu heofizyky im. Subbotina, Lviv. 132-133 (in Ukrainian).

Malyshkov, S. Y., Gordeev, V. F., Shtalin, S. G., Polivach, V. I., Bazhanov, Y. Y., Hauan., T., 2011. Application of the Earth'sNaturalElectromagneticNoisetoGeophysicalProspecting and SerachingforOil. Cornel University.

Salomatin, V.N., 1987. Zakonomernosti geologicheskikh protsessov i yavleniy, ikh svyaz s impulsnoy elektromagnitnoy emissiyey [Regularities of geological processes and phenomena, their connection with pulse electromagnetic emission]. Simferopol (in Russian).

Salomatin, V.N., 1991. Metodicheskiye rekomendatsii po izuchenniyu napryazhenogo sostoyaniya porod metodom registratsii estestvennogo impulsnogo elektromagnitnogo polya Zemli (EIEMPZ) [Methodological recommendations for studying the strained state of rocks by the method of recording the natural electromagnetic field of the Earth (EIEMPZ)]. Simferopol (in Russian).

Tarasov, B. G., Kuzmenko, E.D., Malyarchuk, B. M., Gordiychuk, N. V., Savchuk, Ya. M., 1989. Razrabotka metoda i sredstv kontrolya bureniya na osnove izucheniya geoelektricheskikh potentsialov [Development of a method and means of drilling control based on the study of geoelectrical potentials]. Dep. UkrNIINTI N 2196 - Er89 (in Russian).

Vorobyev, A. A., 1980. Ravnovesiye i preobrazovaniye energii v nedrakh [Equilibrium and the transformation of energy in the depths of the Earth]. Izd. Tomskogo universiteta, Tomsk (in Russian). 